\title{
Induction of Gynogenetic Diploids and Cytological Studies in Honmoroko Gnathopogon caurulescens
}

\author{
Yasuhiro Fujioka*
}

(Received September 10, 1992)

\begin{abstract}
The production of gynogenetic diploids of honmoroko by cold-shock treatment with UV-ir* radiated nigorobuna sperm was examined. $2000 \sim 10000 \mathrm{ergs} / \mathrm{mm}^{2}$ was the optimum UV dose to genetically inactivate nigorobuna sperm which was diluted 100 times by physiological saline solution. The highest yield of gynogenetic diploids was produced after a 40 min duration of cold-shock (CS: $0 \sim 0.3^{\circ} \mathrm{C}$ ) treatment. When the eggs were incubated at $15.0,20.0$, and $25.4^{\circ} \mathrm{C}$, the best times to start CS treatment were 12,7 , and 4.5 min after insemination, respectively. The hatching from the eggs CS treated (for a $40 \mathrm{~min}$ duration) between just after insemination and after $90 \mathrm{~min}$ peaked at $7,12,40,70$, and $90 \mathrm{~min}$ and showed periodical fluctuations. The yield of normal fry showed higher values when the CS treatment was started $3 \sim 7 \mathrm{~min}$ after insemination, but there were low rates of normal fry hatched at times between 10 and $90 \mathrm{~min}$. The egg showed the metaphase of the second maturation division at the time of insemination, and advanced to the anaphase by 5 to $7 \mathrm{~min}$ after insemination. The extrusion of the second polar body was observed $10 \mathrm{~min}$ after insemination. The metaphase of the first cleavage and the prophase of the second cleavage were seen 40 and $60 \mathrm{~min}$ after insemination, respectively. These results suggest that $\mathrm{CS}$ treatment $\left(0^{\circ} \mathrm{C}\right.$, for $40 \mathrm{~min} 3 \sim 7 \mathrm{~min}$ after insemination) is a practical method for the induction of gynogenetic diploids in honmoroko, caused by prevention of the formation of the second polar body.
\end{abstract}

Recently, artificial induction of gynogenetic diploids has been reported in many fishes, since manipulation of chromosomes has been established as a practical method in fish breeding and culture of mono-sexual populations. ${ }^{1-3}$ These techniques are relatively simple and generally employ ultraviolet-ray irradiation to genetically inactivate sperm and physical shock treatment for duplication of the haploid set of egg chromosomes. ${ }^{1-3}$

Honmoroko Gnathopogon caurulescens is a small cyprinid member, which is an endemic form to Lake Biwa located on Honshu Island, Japan. They occupy shallow estuaries during spring and early summer, and move to deeper water in autumn and winter. ${ }^{4)}$ Normally, they mature one year after hatching and die between 2 and 5 years of age., ${ }^{43}$ Honmoroko is one of the important fishery resources in the lake, and the commercial catch is about $200 \sim 300 \mathrm{t}$ per year, though the natural stock has tended to decrease in recent years. Several studies have been performed on reproduction ${ }^{(3)}$ and triploid production $^{73}$ in honmoroko, but few studies have been undertaken on gynogenesis or breeding.

The present study aims to clarify the optimum conditions for induction of gynogenetic diploids in honmoroko, applying thermal shock to eggs activated with ultraviolet-ray irradiated sperm. As well as this, cytological investigation of the eggs was carried out in order to observe the movement of sperm and egg nuclei, and to examine the relationship between the developmental stages of the eggs and thermal shock treatment.

\section{Materials and Methods}

Experiments were performed with honmoroko $\left(2^{+}\right.$and $\left.3^{+}\right)$and nigorobuna Carassius carassius grandoculis $\left(4^{+}\right.$and $\left.5^{+}\right)$reared in Shiga Prefectural Fishery Experimental Station. Eggs of honmoroko were obtained from $3 \sim 7$ females injected with $100 \mathrm{IU}$ (about $5 \mathrm{IU} / \mathrm{g}$ ) human chorionic gonadotropin $10 \mathrm{~h}$ prior to the start of each experiment. Sperm of nigorobuna was collected from $5 \sim 10$ individuals, and was diluted 100 times with physiological saline solution $(7.5 \mathrm{~g}$ $\mathrm{NaCl}, 2.0 \mathrm{~g} \mathrm{KCl}, 2.0 \mathrm{~g} \mathrm{CaCl}_{2}, 0.2 \mathrm{~g} \mathrm{NaHCO}$, $1000 \mathrm{~m} /$ distilled water, adjusted to $\mathrm{pH} 7.0$ ) just before each experiment. In the first experiment to determine the dose of UV (ultraviolet-

* Shiga Prefectural Fisheries Experimental Station, Hassaka, Hikone, Shiga 522, Japan (藤岡康弘：㶌贺集水 産試験場). 
ray)-irradiation required to genetically inactivate the sperm, sperm $(1 \mathrm{~m} l)$ which was spread on a glass Petri dish $(90 \mathrm{~mm}$ in diameter) was exposed to UV over a range of $20 \sim 30000 \mathrm{ergs} / \mathrm{mm}^{2}$ and was used to fertilize $243 \sim 448$ honmoroko eggs. 416 and 306 honmoroko eggs were fertilized with non-irradiated sperm of honmoroko and nigorobuna for control and hybrid control, respectively. Survival of embryos 4 days after fertilization, and hatching and incidence of haploid syndrome ${ }^{8}$ ) in hatched fry incubated at room temperature $\left(16.0 \sim 22.0^{\circ} \mathrm{C}\right)$ were recorded.

The second experiment determined the optimum duration for cold shock treatment (CS). Batches of $185 \sim 655$ eggs from a single female were fertilized with nigorobuna sperm irradiated with $3000 \mathrm{ergs} / \mathrm{mm}^{2}$ of UV, were kept in water at $23.8^{\circ} \mathrm{C}$ for $5 \mathrm{~min}$, and then were transferred directly to cooled water $\left(0 \sim 0.3^{\circ} \mathrm{C}\right)$ for $10 \sim 60 \mathrm{~min}$. After $\mathrm{CS}$, the eggs were incubated at room temperature $\left(16.0 \sim 24.5^{\circ} \mathrm{C}\right.$ ), and the survival of embryos and the yield of normal fry hatched were counted in six replicates.

The third experiment attempted to clarify the relationship between incubation temperature prior to the beginning of $\operatorname{CS}\left(0 \sim 0.3^{\circ} \mathrm{C}\right)$ and the best time to start CS treatment. Eggs fertilized with UV-irradiated $\left(3000 \mathrm{ergs} / \mathrm{mm}^{2}\right)$ sperm of nigorobuna were incubated at three different temperatures $\left(15.0,20.0\right.$, and $\left.25.4^{\circ} \mathrm{C}\right)$ and then CS was carried out for $40 \mathrm{~min}$ at $1 \sim 14 \mathrm{~min}$ after insemination. After CS, eggs were incubated at room temperature $\left(16.0 \sim 24.5^{\circ} \mathrm{C}\right)$ and the survival of embryos, hatching and the yield of normal fry were recorded.

The fourth experiment was performed to observe the relationship between the developmental stages of fertilized eggs, the time for starting CS and the rate of production of normal fry. Honmoroko eggs fertilized with UV-irradiated $\left(3000 \mathrm{ergs} / \mathrm{mm}^{2}\right)$ sperm of nigorobuna were incubated at $20^{\circ} \mathrm{C}$, and then $\mathrm{CS}\left(0 \sim 0.3^{\circ} \mathrm{C}, 40 \mathrm{~min}\right.$ duration) was carried out between just after insemination and after $90 \mathrm{~min}$. Simultaneously, each of the eggs were fixed in Bouin fluid for histological examination. The eggs were embedded in paraffin and sections $(7 \mu \mathrm{m})$ were stained with hematoxylin and eosin.

The hatching rate of normal larvae was the primary criterion to estimate the success of induced diploidization, with all percentages expressed in relation to the initial egg number except for the percentage of incidence of haploid syndrome in the first experiment.

\section{Results}

\section{Experiment $I$}

As shown in Fig. 1, along with the increase in the UV dose, the survival of embryos and hatching decreased abruptly, and attained the lowest levels at 150 and $100 \mathrm{ergs} / \mathrm{mm}^{2}$, respec-

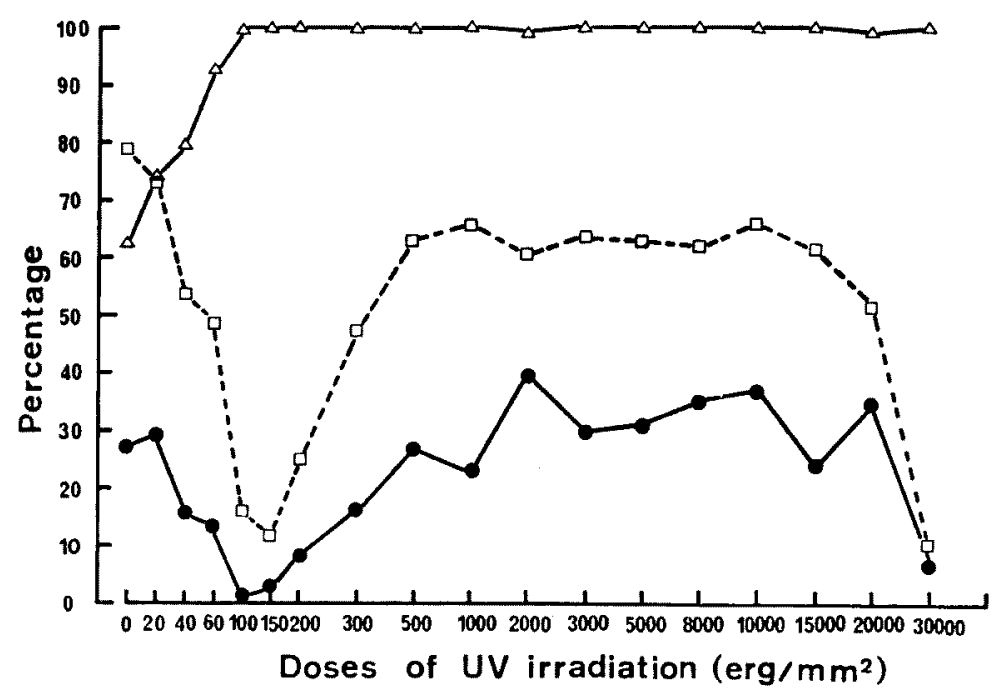

Fig. 1. Changes in survival of embryos $(\square)$, hatching $(\bullet)$, and haploid syndrome $(\triangle)$ of honmoroko eggs fertilized with UV-irradiated nigorobuna sperm. 
tively. However, both values increased again at more than $200 \mathrm{ergs} / \mathrm{mm}^{2}$, and were about 60 and $30 \%$ at doses of $2000 \sim 20000 \mathrm{ergs} / \mathrm{mm}^{2}$, respectively. Lower rates occurred at a higher dose $\left(30000 \mathrm{ergs} / \mathrm{mm}^{2}\right)$ of UV irradiation. More than $99.4 \%$ of hatched fry from eggs fertilized with sperm irradiated with UV higher than 100 ergs $/ \mathrm{mm}^{2}$ were deformed and they died within a day after hatching, showing a haploid syndrome characterized by a distorted body, abnormal retina and a short tail. ${ }^{8}$. The hatching of normal control and hybrids were 82.7 and $27.1 \%$, respectively. $62.7 \%$ of hatched fry from hybrid eggs (honmoroko eggs fertilized with normal nigorobuna sperm) showed abnormal shapes like haploid syndrome, while the others $(27.3 \%)$ died within a week after hatching despite being visually similar to control fry in shape.

\section{Experiment $I I$}

Figure 2 shows the survival and hatching of normal fry from eggs which were administered with CS $5 \mathrm{~min}$ after insemination for $10 \sim 60 \mathrm{~min}$ duration. The survival of embryos gradually decreased with as the duration increased. On the other hand, the yields of normal fry were lower than $0.5 \%$ at durations between 0 and $20 \mathrm{~min}$, but a longer duration $(30 \sim 60 \mathrm{~min})$ of CS gave values higher than $2 \%$, and the highest yield was found at $40 \mathrm{~min}$ of CS duration.

\section{Experiment III}

Low survival of embryos, hatching and yield of normal fry were observed from the eggs CS treated (for $40 \mathrm{~min}$ ) by $9 \mathrm{~min}$ after insemination

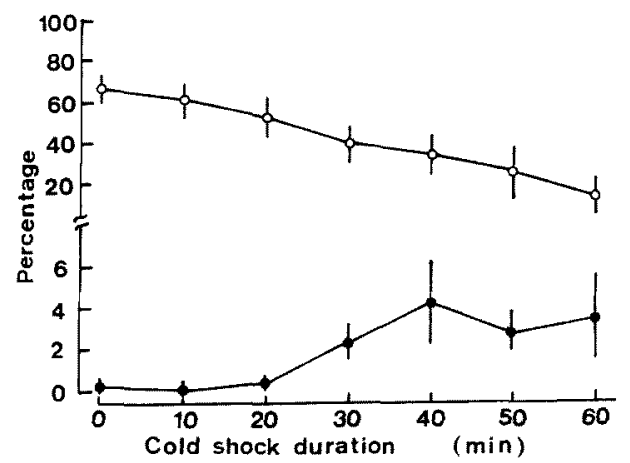

Fig. 2. Effect of duration of cold-shock $\left(0 \sim 0.3^{\circ} \mathrm{C}\right)$ on the survival of embryos $(O)$ and yield of normal fry (๑) in honmoroko eggs fertilized with UV. irradiated nigorobuna sperm.

Vertical bars represent standard errors of the means $(n=6)$. when the eggs were incubated at $15.0^{\circ} \mathrm{C}$ (Table 1 ). However, these values increased $10 \mathrm{~min}$ after insemination, and showed a peak at 12 or $13 \mathrm{~min}$. At 20.0 and $25.4^{\circ} \mathrm{C}$, values peaked at $7 \mathrm{~min}$ and 4.5 min, respectively.

\section{Experiment IV}

Hatching from the eggs CS treated (for $40 \mathrm{~min}$ ) at an elapsed time range from just after insemination (about $10 \mathrm{~s}$ ) to $90 \mathrm{~min}$ after insemination showed periodical fluctuations and peaked at 7, 12, 40, 70, and $90 \mathrm{~min}$ (Fig. 3). The yield of normal fry showed higher values when the CS was given at $3 \sim 7 \mathrm{~min}$ after insemination but was lower $(0 \sim 1.9 \%)$ after $10 \mathrm{~min}$, and a few normal fry hatched at $10 \sim 12,20 \sim 35$, and $45 \sim 60 \mathrm{~min}$.

\section{Experiment $V$}

Just after insemination, several nigorobuna sperm were observed in the micropyle along the honmoroko egg membrane (Fig. 4-A), and there was a single sperm-head in the egg (Fig. 4-B). By 7 min after insemination, the sperm-head had moved to the center of blastodisc with forming sperm aster (Fig. 4-C), and began swelling a little 10 min after insemination. On the other hand, the egg showed the metaphase of the second maturation division at the time of insemination (Fig. 4-D), and advanced to the anaphase by 5 to $7 \mathrm{~min}$ after insemination (Fig. 4-E). The extrusion of the second polar body was observed $10 \mathrm{~min}$ after insemination (Fig. 4-F). The sperm and egg nucleus swelled and transformed into a male and female pronucleus $15 \mathrm{~min}$ after insemination (Fig. 4-G, H), and then both pronuclei conjugated $20 \sim 30 \mathrm{~min}$ after insemination (Fig. 4-1). $40 \mathrm{~min}$ after insemination, the metaphase chromosomes of the female pronucleus origin were found to form the equatorial plate of the first cleavage (Fig. 5-A), and a dense chromatin body prospected originating from the male pronucleus was situated near the egg nucleus (Fig. 5-B). $50 \mathrm{~min}$ after insemination, the telophase of the first cleavage was observed, and a dense chromatin body lay along the first cleavage furrow (Fig. 5-C). $60 \mathrm{~min}$ after insemination, the prophase of the second cleavage was observed (Fig. 5-D), the dense chromatin body swelling again in one blastomere (Fig. 5-E). And a dense chromatin body closely located to the one nucleus of the second cleavage (Fig. 5-F). $70 \mathrm{~min}$ after insemination, the fertilized eggs showed telophase of the second cleavage. 
Table 1. Survival of embryos, hatching, and yield of normal fry from the eggs, which were fertilized with UV-irradiated nigorobuna sperm and were treated CS for $40 \mathrm{~min}$ at an elapsed time range of $1 \sim 14 \mathrm{~min}$ after insemeination, incubated at three different temperatures

\begin{tabular}{|c|c|c|c|c|c|c|}
\hline \multirow{2}{*}{$\begin{array}{l}\text { Incubation } \\
\text { temperature } \\
\left({ }^{\circ} \mathrm{C}\right)\end{array}$} & \multirow{2}{*}{$\begin{array}{l}\text { Time of } \\
\text { treatment } \\
\text { (min) }\end{array}$} & \multirow{2}{*}{$\begin{array}{l}\text { No. of eggs } \\
\text { used }\end{array}$} & \multirow{2}{*}{$\begin{array}{c}\text { Survival of } \\
\text { embryos } \\
(\%)\end{array}$} & \multirow{2}{*}{$\begin{array}{c}\text { Hatching } \\
(\%)\end{array}$} & \multicolumn{2}{|c|}{ Yield of normal fry } \\
\hline & & & & & $\begin{array}{l}\text { No. of normal } \\
\text { fry }\end{array}$ & $(\%)$ \\
\hline \multirow{11}{*}{15.0} & 4 & 605 & 7.6 & 1.3 & 2 & 0.3 \\
\hline & 5 & 646 & 8.0 & 2.8 & 8 & 1.2 \\
\hline & 6 & 267 & 8.2 & 1.9 & 2 & 0.7 \\
\hline & 7 & 207 & 9.2 & 1.4 & 1 & 0.5 \\
\hline & 8 & 301 & 10.6 & 0.7 & 0 & 0 \\
\hline & 9 & 303 & 9.9 & 1.0 & 1 & 0.3 \\
\hline & 10 & 326 & 19.9 & 5.2 & 6 & 1.8 \\
\hline & 11 & 232 & 36.6 & 20.3 & 26 & 11.2 \\
\hline & 12 & 325 & 44.9 & 25.5 & 39 & 12.0 \\
\hline & 13 & 257 & 53.7 & 26.5 & 29 & 11.3 \\
\hline & 14 & 301 & 49.2 & 19.3 & 22 & 7.3 \\
\hline \multirow{10}{*}{20.0} & 1 & 275 & 4.7 & 3.6 & 8 & 2.9 \\
\hline & 3 & 207 & 25.1 & 20.3 & 39 & 18.8 \\
\hline & 4 & 218 & 28.9 & 18.8 & 29 & 13.3 \\
\hline & 5 & 157 & 45.2 & 34.4 & 42 & 26.8 \\
\hline & 6 & 60 & 53.3 & 40.0 & 17 & 28.3 \\
\hline & 7 & 107 & 78.5 & 58.9 & 39 & 36.4 \\
\hline & 8 & 57 & 68.4 & 54.4 & 4 & 7.0 \\
\hline & 9 & 57 & 63.2 & 43.9 & 0 & 0 \\
\hline & 10 & 275 & 75.6 & 18.5 & 3 & 1.1 \\
\hline & 12 & 63 & 76.2 & 41.3 & 1 & 1.6 \\
\hline \multirow{9}{*}{25.4} & 2 & 317 & 9.1 & 5.7 & 9 & 2.8 \\
\hline & 3 & 201 & 10.9 & 7.0 & 9 & 4.5 \\
\hline & 3.5 & 357 & 5.9 & 2.0 & 4 & 1.1 \\
\hline & 4 & 418 & 23.0 & 13.6 & 40 & 9.6 \\
\hline & 4.5 & 345 & 33.9 & 22.6 & 51 & 14.8 \\
\hline & 5 & 376 & 39.9 & 23.1 & 42 & 11.2 \\
\hline & 5.5 & 119 & 38.7 & 16.0 & 5 & 4.2 \\
\hline & 6 & 272 & 37.9 & 20.2 & 4 & 1.5 \\
\hline & 6.5 & 535 & 35.9 & 19.4 & 2 & 0.4 \\
\hline
\end{tabular}

* Time to start cold shock treatment after insemination.

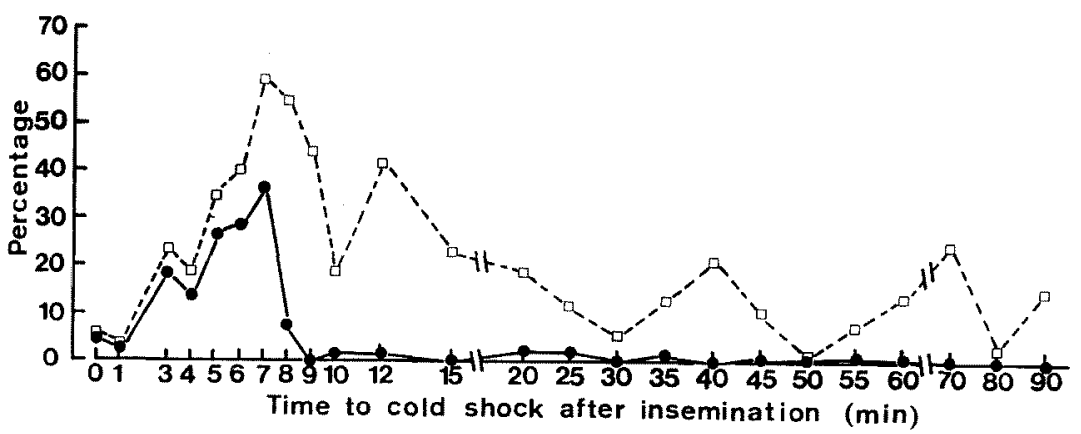

Fig. 3. Relationships between the time of start of cold-shock treatment $\left(0 \sim 0.3^{\circ} \mathrm{C}, 40 \mathrm{~min}\right)$ and hatching $(\square)$, and yield of normal fry ( $)$ in honmoroko eggs. 


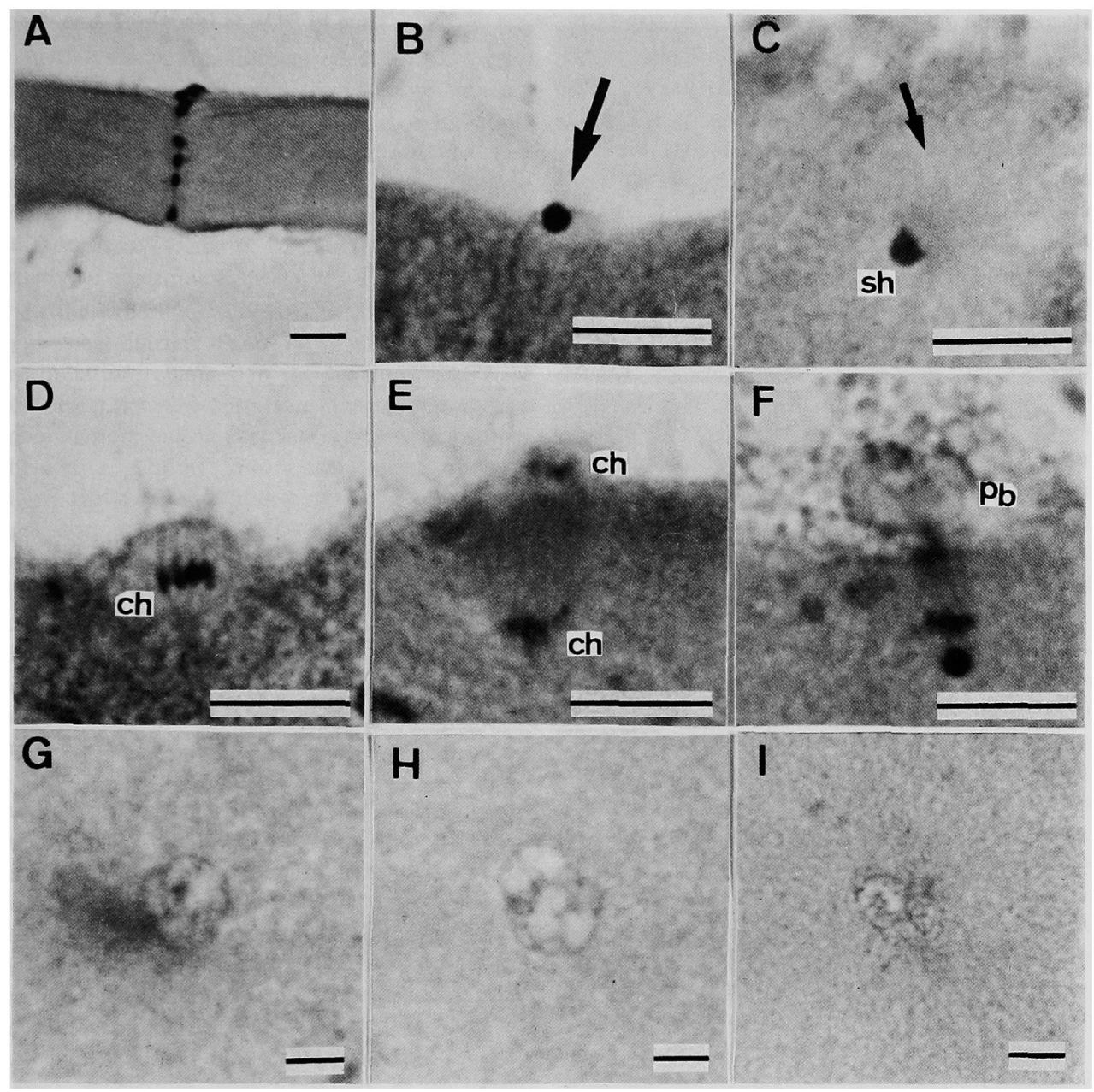

Fig. 4. Cytological observations on fertilization in the honmoroko eggs inseminated with UV-irradiated nigorobuna sperm. Scale bars indicate $10 \mu \mathrm{m}$. ch: chromosome.

A: Several nigorobuna sperm in the micropyle along the honmoroko egg membrane just after insemination.

B : A sperm-head (arrowed) on the blastodisc just after insemination.

C: The sperm-head (sh) moved to a deeper part of the blastodisc as it formed a spermaster (arrowed) 7 min after insemination.

D: Metaphase of the second maturation division of the honmoroko egg at the time of insemination.

E : Anaphase stage of the egg nucleus $7 \mathrm{~min}$ after insemination.

F : The division of the second polar spindle $10 \mathrm{~min}$ after insemination. pb: second polar body.

G: Male pronucleus $15 \mathrm{~min}$ after insemination.

$\mathrm{H}$ : Female pronucleus 15 min after insemination.

I : Conjugated pronuclei $30 \mathrm{~min}$ after insemination. 


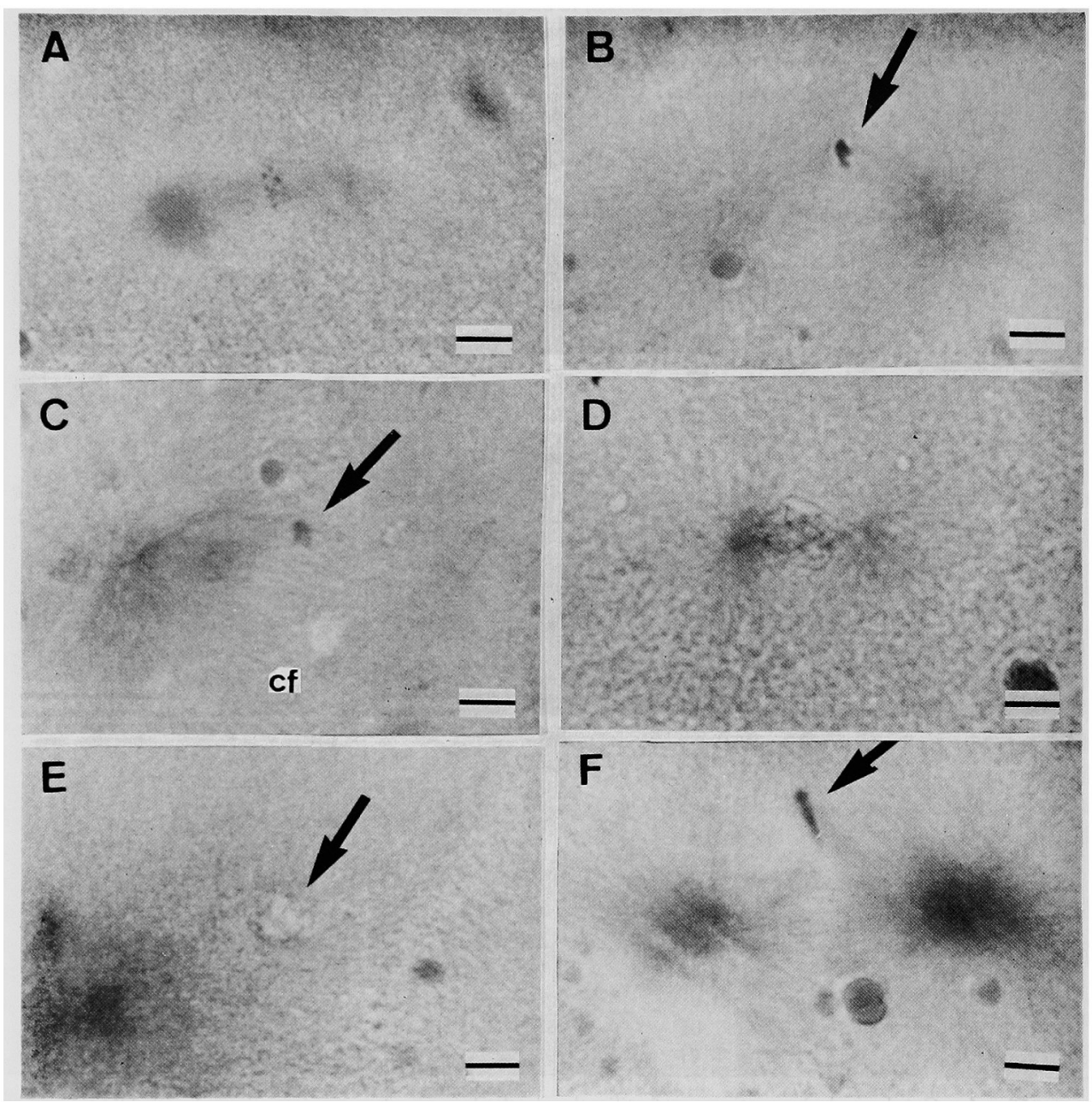

Fig. 5. Cytological observations on the early development in honmoroko eggs inseminated with UV-irradiated nigorobuna sperm. Scale bars indicate $10 \mu \mathrm{m}$.
A : The metaphase of the first cleavage $40 \mathrm{~min}$ after insemination.
B : A dense chromatin body (arrowed) originated from the male pronucleus lying near the egg nucleus in fig. A.
C: A dense chromatin body (arrowed) situated in the first cleavage furrow (cf) $50 \mathrm{~min}$ after insemination.
D: Prophase of the second cleavage $60 \mathrm{~min}$ after insemination.
E : A sperm nucleus (arrowed) reswelled in one blastomere 60 min after insemination.
F : A dense chromatin body (arrowed) located near one nucleus of the second cleavage.

\section{Discussion}

Artificial induction of gynogenetic diploids have been reported in many fishes. ${ }^{1-3}$ ) The optimum conditions for producing the diploid gynogenesis of honmoroko by cold shock were demonstrated in the present study.
Nigorobuna was employed as a donor fish for sperm in the study because viable fry cannot be obtained even if normal nigorobuna sperm is used to fertilize honmoroko eggs. For this reason, normal fry from eggs fertilized with UVirradiated nigorobuna sperm were decided as gynogenetic diploids of honmoroko. Similar methods were reported by Suzuki et $a l^{{ }^{\theta)}}$ in 
loach and Taniguchi et al. $^{10}$ ) in ayu.

In this study, the Hertwig effect ${ }^{11}$ was clearly demonstrated, and although the UV dose inducing the lowest survival of embryos was a little low compared with the medaka Oryzja latipes ${ }^{12}$ and some salmoniformes, ${ }^{B}$ ) it was near that of hirame Paralichthys olivaceus. ${ }^{13)}$ A UV dose of $2000 \sim$ $3000 \mathrm{ergs} / \mathrm{mm}^{2}$ seems to be enough to genetically inactivate nigorobuna sperm.

In the experiment, when CS treatment for the eggs was started from $10 \mathrm{~s}$. to $90 \mathrm{~min}$ after insemination, changes in the hatching and yield of normal fry were correlated during $10 \mathrm{~min}$ after insemination, but no correlation was seen between these after $12 \mathrm{~min}$. From histological observations, the developmental stages of the fertilized eggs during $0 \sim 10,20 \sim 50$, and $55 \sim 80 \mathrm{~min}$ after insemination were the second meiosis, and the first and second mitosis, respectively. Therefore, almost all the gynogenetic diploids were considered to be induced by the chromosome duplication caused by the prevention of formation of the second polar body, because many normal fry were yielded when the CS was only given $3 \sim 7 \mathrm{~min}$ after insemination. On the other hand, normal fry which hatched from the eggs treated with $\mathrm{CS}$ from 20 to $60 \mathrm{~min}$ after insemination may be gynogenetic diploids induced by suppression of the first or second mitosis. Similar results were reported by Nagoya et al. ${ }^{4)}$ CS treatment used in this study, however, was not effective in the suppression of mitosis, since normal fry were scarcely obtained. And also when CS was applied after $10 \mathrm{~min}$, hatching showed periodical fluctuation and appeared in 4 peaks. These peaks corresponded to the telophase of the second meiosis $(12 \mathrm{~min})$, or the metaphase ( 40 min) or telophase $(70 \mathrm{~min}$ ) of mitosis (not observed in the developmental stage at $90 \mathrm{~min}$ ). These stages may be related to the increase in tolerance of eggs to thermal shock, since the eggs developed as haploid fry.

In order to duplicate the haploid set of chromosomes of the egg nucleus, several different methods such as cold shock, heat shock, hydrostatic pressure and chemical treatment have been employed. ${ }^{1-3}$ Makino and Ojima ${ }^{15)}$ first reported that refrigeration prevented the second maturation division and caused chromosome duplication in the eggs of fish. Onozato ${ }^{16)}$ observed the disappearance of spindle poles when applying hydrostatic pressure at the first mitosis in salmonid eggs, and Oshiro ${ }^{17)}$ also reported the disappearance of aster and spindle fibers at the second meiosis of loach eggs treated by coldshock. Therefore, the mechanism of induction of artificial gynogenetic diploids is considered to involve the destruction of the division apparatus such as spindle poles or fibers due to physical shock. In this study, the yield of gynogenetic diploids increased as time elapsed after insemination to $7 \mathrm{~min}$ when the eggs incubated at $20^{\circ} \mathrm{C}$ were treated by CS. At this time, the developmental stage of fertilized eggs was the anaphase of the second meiosis, separating the daughter chromosome sets. These results suggest that distance between the daughter chromosome sets during the second meiosis may be an important key in inducing the formation of the diploid set of chromosomes by CS. And the optimum starting time of CS in honmoroko eggs appeared to be the mid to late anaphase of the second meiosis.

According to Ojima and Asano, ${ }^{19}$ ) the sperm head remains without transformation and lies in a location close to the spindle of the egg nucleus in the egg of ginbuna Carassius auratus langsdofii, known for natural gynogenetic development. In the present study, however, the sperm nucleus swelled and transformed into a male pronucleus, though a male nucleus was excluded completely after the first mitosis. A similar observation was reported in the production of gynogenetic diploids in the loach. ${ }^{17}$ These results indicate that the process of the exclusion of the sperm nucleus in natural gynogenetic development such as ginbuna differs slightly from artificial gynogenetic development using UV-irradiated sperm.

Artificial gynogenetic techniques are well known to be useful in a fish culture for the production of an inbred line or mono-sexual broods. ${ }^{1-3}$ ) Therefore, further studies are needed to estimate the characteristics of the gynogenetic diploids of honmoroko and to clarify the optimum conditions for producing homozygous gynogenetic diploids by inhibition of the first mitosis as established in several fishes. ${ }^{19-23)}$

\section{Acknowledgments}

I am grateful to Dr. Y. Ojima, Japan Fish Bioscience Institute, and Dr. M.J. Hutchison, Nikko Laboratory, National Research Institute of Aquaculture, for their critical reading of the manuscript. I also wish to thank Dr. H. Onozato and Dr. T. Nakanishi, National Research Institute, 
Prof. R. Suzuki, Faculty of Applied Biological Science, Hiroshima University, and Dr. M. Iwata, Nikko Laboratory, National Research Institute of Aquaculture, for their useful advice and help.

This study was supported by a Grant-in Aid from the Ministry of Agriculture, Forestry, and Fisheries of Japan.

\section{References}

1) C. E. Purdom: Genetic engineering by the manipulation of chromosomes. Aquaculture, 33, 287-300 (1983).

2) G. H. Thorgaard: Chromosome set mainpulation and sex control in tish, in "Fish Physiology" (ed, by W.S. Hoar, D. J. Randall, and E. M. Donaldson), Vol. 9, Academic Press, New York, 1983, pp. 405-434.

3) K. Fujino: Historical aspects of research and development of genome manipulation technologies, in "Chromosome Manupulation and its Application for Aquaculture" (ed. by R. Suzuki), Koseisha Koseikaku, Tokyo, 1989, pp. 1-20 (in Japanese).

4) M. Nakamura: The life history of a cyprinid fish, Gnathopogon alongatus caurulescens (Sauvage) in Lake Biwa. Nippon Suisan Gakkaishi, 15, 88-96 (1959).

5) I. Maki: Population studies of honmotoko, Gnathopogon caerulescens Sauvage, in Lake Biwa, Japan. 1. On the critical life-cycle stages related to the annual fuctuation of the population. Jpn. J. Ecol., 16, 183-190 (1966).

6) K. Okuzawa, K. Furukawa, K. Aida, and I. Hanyu: Annual reproductive cycle of the honmoroko Gnathopogon elongatus caerulescens. Nippon Suisan Gakkaishi, 52, $1957-1960$ (1986).

7) K. Ueno: Sterility and secondary sexual character of triploid Gnathopogon elongatus caerulescens. Suisanikushu (Fish Genet. Breed. Sci.), 10, 37-41 (1985) (in Japanese).

8) H. Onozato and $E$. Yamaha: Induction of gynogenesis with ultraviolet rays in four species of salmoniformes. Nippon Suisan Gakkaishi, 49, 693-699 (1983).

9) R. Suzuki, T. Oshiro, and T. Nakanishi: Survival, growth and fertility of gynogenetic diploids induced in the eyprinid loach, Misgurnus angullicaudatus. Aquaculture, 48, 45-55 (1985).

10) N. Taniguchi, H.S. Han, and H. Hatanaka: Induction of diploid gynogenetic ayu by UV-irradiated sperm of shishamo smelt with verification by genetic marker. Stisanzoshoku,
$39,41-45$ (1991).

11) H. Onozato: The "Hertwig effect" and gynogenesis in chum salmon Oncorhynchus keta eggs fertilized with ${ }^{60} \mathrm{Co}$ r-ray itradiated milt. Nippon Suisan Gakkaisht, 48, 12371244 (1982)

12) K. Ijiri and N. Egami: Hertwig effect caused by UVirradiation of sperm of Oryzia latipes (teleost) and its photoreactivation. Mutation Res., 69, 241-248 (1980).

13) K. Tabata, S. Gorie, and K. Nakamura: Induction of gynogenetic diploid in hirame Paralichthys ollvaceus, Nippon Suisan Gakkaishi, 52, 1901-1904 (1986).

14) H. Nagoya, T. Kimoto, and H. Onozato: Diploid gynogenesis induced by suppression of the second or third cleavage in the goldfish, Crassius auratus. Bull. Natl. Res. Inst. Aquaculture, 18, 1-6 (1990).

15) S. Makino and Y. Ojima: Formation of the diploid ege nucleus due to suppresion of the second maturation division induced by refrigeration of fertilized eggs of the carp Cypinus carpio. Cytologia, 13, 55-60 (1943).

16) H. Onozato: Diploidization of gynogentically activated salmonid eggs wsing hydrostatic pressure. Aquaculure, 43, 91-97 (1984).

17) T. Oshiro: Cytological studies on diploid gynogenesis induced in the loach Misgunus anguillicaudatus. Nippon Suisan Gakkaishi, 53, 933-939 (1987).

18) Y. Ojima and N. Asano: A cytological evidence for gynogenetic development of the ginbuna (Carassius auratus longsdorfii). Pro. J. Academy, 53, Ser. B, 4, 138-142 (1977).

19) G. Streisinger, C. Walker, N. Dower, D. Knauber, and F. Singer: Production of clones of homozygous diploid zebra fish (Brachydanio rerio). Nature, 291, 293-296 (1981).

20) K. Naruse, K. Ijiri, A. Shima, and N. Egami; The production of cloned fish in the medaka (Oryzia latipes). J, Exp. Zool., 236, 335-341 (1985).

21) K. Tabata and $\mathrm{S}$. Gorie: Induction of gynogentic diploid in Paralichthys olivaveus by suppression of the Ist cleavage with special reference to their survival and growth. Nippon Suisan Gakkaishi, 54, 1867-1872 (1988).

22) N. Taniguchi, S. Seki, J. Fukai and A. Kijima: Induction of two types of gynogenetic diploid by hydrostatic pressure shock and verification by genetic marker in ayu. Nippon Sulsan GakAaishi, 54, 1483-1491 (1988).

23) J. Komen, A. B. Bongers, C. J. J. Richter, W. B. van Muiswinkel, and E. A. Huisman: Gynogenesis in common carp (Cyprinus corpio L). II. The production of homozygous gynogenetic clones and $F_{1}$ hybrids. Aquaculture, 92, 127$14 !(1991)$. 